\title{
Diets for sheeps whit levels of residual frying oil consequences on ingestive behavior
}

\section{Dietas para ovinos contendo teores de óleo residual de frituras consequências sobre o comportamento ingestivo}

\author{
Eduardo Lucas Terra Peixoto ${ }^{1 *}$; Ivone Yurika Mizubuti²; Elzânia Pereira Sales ${ }^{3}$; \\ Patrícia Guimarães Pimentel ${ }^{3}$; Odimári Pricila Prado-Calixto ${ }^{2}$; \\ Leandro das Dores Ferreira da Silva'; ${ }^{2}$ Mikael Neumann ${ }^{4}$; Edson Luiz de Azambuja \\ Ribeiro $^{2}$; Elizabeth dos Santos Moura ${ }^{5}$ Fernando Luiz Massaro Júnior ${ }^{6}$
}

\begin{abstract}
The objective of this study was to evaluate the ingestive behavior of lambs fed diets containing different levels of residual frying oil. Different residual frying oil concentrations $\left(0,20,40,60\right.$ and $80 \mathrm{~g} \mathrm{~kg}^{-1} \mathrm{dry}$ matter base) in the diets of lambs were evaluated. The experimental diets were formulated to contain $12.8 \%$ crude protein $(\mathrm{CP})$ with a $60: 40$ roughage:concentrate ratio. In each observation period, the following variables were measured: time spent eating, time spent ruminating, time spent idle, and number and time of ruminating chews per ruminated bolus. Animals were randomly allocated to treatment groups according to a Latin square design, with five treatments and five experimental periods. The average values were analyzed using regression analysis to $5 \%$. There was no difference for the time spent feeding, ruminating and being idle. No differences in daily feeding number, total chewing time, number of rumination boluses, number of rumination chews per bolus, rumination chew time per bolus and feeding efficiency were observed. The efficiency of rumination for dry matter and neutral detergent fiber showed a decreased linear effect. It can be concluded that the inclusion of residual frying oil does not affect activities of feeding, rumination and being idle as well as the parameters of rumination chewing, but it does decrease the efficiency of rumination.
\end{abstract}

Key words: Feeding. Idle. Lipids. Rumination. Ruminating chews.

\section{Resumo}

Objetivou-se avaliar o comportamento ingestivo de carneiros alimentados com dietas contendo teores de óleo residual de frituras. Foram avaliados os teores 0, 20, 40, 60 e $80\left(\mathrm{~g} \mathrm{~kg}^{-1}\right.$ base MS) de inclusão de óleo residual de frituras em dietas para carneiros. As dietas foram formuladas para conterem 12,8\% de PB mantendo uma relação volumoso:concentrado de 60:40. Foram usados cinco carneiros com peso inicial de $36,8 \pm 3,3 \mathrm{~kg}$. O comportamento ingestivo foi avaliado no $11^{\circ}$ dia de cada período experimental, através da medição do tempo gasto em alimentação, ruminação e descanso por meio

${ }^{1}$ Prof. Dr., Universidade Federal do Sul e Sudeste do Pará, UNIFESSPA, Marabá, PA, Brasil. E-mail: eltpeixoto@unifesspa.edu.br

2 Profs. Drs., Universidade Estadual de Londrina, UEL, Londrina, PR, Brasil. E-mail: mizubuti@uel.br; odimari@uel.br; leandro@ uel.br; elar@uel.br

${ }^{3} \operatorname{Prof}^{\mathrm{as}} \mathrm{Dr}^{\mathrm{as}}$, Universidade Federal do Ceará, Fortaleza, UFC, CE, Brasil. E-mail: elzania@hotmail.com; pgpimentel@hotmail.com

${ }^{4}$ Prof. Dr., Programa de Pós-Graduação em Ciências Veterinárias, Saúde e Produção Animal Sustentável da Universidade Estadual do Centro-Oeste, UNICENTRO, Guarapuava, PR, Brasil. E-mail: neumann.mikael@hotmail.com

${ }_{5}^{5}$ Pós-Doutoranda, Programa de Pós-Graduação em Saúde e Produção Animal na Amazônia, Universidade Federal Rural da Amazônia, UFRA, Belém, PA, Brasil. E-mail: elizazootec@hotmail.com

${ }^{6}$ Pesquisador, UEL, Londrina, PR, Brasil. E-mail: nandomassar@hotmail.com

* Author for correspondence 
de observações visuais realizadas a cada 5 minutos, durante 24 horas. No mesmo dia, foi realizada a contagem do número de mastigações merícicas e do tempo despendido para ruminação de cada bolo, com a utilização de um cronômetro digital. O delineamento experimental utilizado foi quadrado latino (5 x 5). Os valores médios foram analisados por meio de análise de regressão à $5 \%$. Não houve efeito da adição do óleo residual de frituras sobre o tempo de alimentação, ruminação e ócio, nas variáveis relativas a mastigação merícica e eficiência de alimentação. Houve efeito linear decrescente para a eficiência de ruminação da MS e do FDN. Conclui-se que a inclusão de óleo residual de frituras não afetou as atividades de ingestão, ruminação e ócio, bem como, os parâmetros da mastigação merícica, mas reduz a eficiência de ruminação.

Palavras-chave: Lipídeo. Alimentação. Ruminação. Ócio. Mastigação Merícica.

\section{Introduction}

The intensification of ruminant production systems has driven the search for alternatives that enable the best food combinations and costreduction diets. Among the available technologies, the use of industrial byproducts has been progressive. The successful use of byproducts has often been limited because of insufficient knowledge about the nutritional and productive properties of animals fed industrial byproducts in the diet. However, the physical and chemical properties of industrial byproducts differ from byproducts of forage plants, making their degradation and passage through the gastrointestinal tract different (CARVALHO et al. 2006). These differences may affect intake behavior, which is influenced by the physical structure and the chemical composition of diets (CARVALHO et al., 2004). The study of intake behavior is necessary to evaluate foods and diets, to elucidate problems related to decreased consumption, and to adjust the feeding regime of the animals to maximize production and economic performance (AGY et al., 2012).

Intake behavior has been studied with regard to the characteristics of food, rumen motility, alertness and the climatic environment. The diversity of objectives and experimental conditions yielded a range of techniques for recording data in the form of visual observations and semi-automatic and automatic records (MACEDO et al., 2007).

Among the benefits of inclusion of oil in ruminant nutrition are: reduction in production costs, increase in energy density of the diet, better utilization of nutrients, manipulation of fatty acid composition of milk and meat, reduction of negative consequences of inclusion of large amounts of energy concentrates in the feeding of these animals and reduction of methane production. However, the oil also has undesirable effects, such as the reduction in the dry matter digestibility (DM) and the reduction in the acetate: propionate ratio, with consequent reduction of milk fat (SILVA et al., 2007; RODRIGUES FILHO, 2011). There are few studies in the literature concerning the use of residual frying oil in the diet of sheep that enable us to understand aspects of production and nutrition. The objective of this study was to evaluate the intake behavior of sheep fed diets with different levels of residual frying oil and to generate a better basis for the processes that control the intake of diets containing fat sources.

\section{Materials and Methods}

The experiment was performed at the ruminant metabolism sector of the farm school of Londrina State University, Paraná, Brazil. Analyses of the collected material were carried out at the Animal Nutrition Laboratory of the Londrina State University, Brazil. All protocols for the research have been approved by the Animal Ethics Committee at the same institution under register number CEUA 46/12 process 28732/11.

Residual frying oil at inclusion levels of $0,20,40,60$ and $80 \mathrm{~g} \mathrm{~kg}^{-1} \mathrm{DM}$ base in diets for lambs was evaluated. Diets were formulated to be isonitrogenous (Table 1) and were increased by 
$10 \%$ to the requirements according to the (NRC, 2007). All diets were kept at a forage:concentrate ratio of 60:40, where the source of forage was sorghum silage and where the concentrate ration sources were, corn, wheat bran, soybean meal, a vitamin and mineral mixture, and residual frying oil (Table 1).

Table 1. Food and chemical compositions in the dry matter base of diets containing different levels of residual frying oil for lambs.

\begin{tabular}{|c|c|c|c|c|c|}
\hline \multirow{2}{*}{ Feed } & \multicolumn{5}{|c|}{ Levels of residual frying oil $\left(\mathrm{g} \mathrm{kg}^{-1} \mathrm{DM}\right)$} \\
\hline & 0 & 20 & 40 & 60 & 80 \\
\hline Sorghum silage $\left(\mathrm{g} \mathrm{kg}^{-1} \mathrm{DM}\right)$ & 600.0 & 600.0 & 600.0 & 600.0 & 600.0 \\
\hline Corn $\left(\mathrm{g} \mathrm{kg}^{-1} \mathrm{DM}\right)$ & 189.4 & 171.0 & 152.7 & 134.3 & 116.0 \\
\hline Wheat bran $\left(\mathrm{g} \mathrm{kg}^{-1} \mathrm{DM}\right)$ & 81.2 & 73.3 & 65.4 & 57.6 & 49.7 \\
\hline Soybean meal $\left(\mathrm{g} \mathrm{kg}^{-1} \mathrm{DM}\right)$ & 109.4 & 115.6 & 121.9 & 128.1 & 134.3 \\
\hline Mix mineral vitamin $\left(\mathrm{g} \mathrm{kg}^{-1} \mathrm{DM}\right)$ & 20.0 & 20.0 & 20.0 & 20.0 & 20.0 \\
\hline Residual frying oil ( $\left.\mathrm{g} \mathrm{kg}^{-1} \mathrm{DM}\right)$ & 0.0 & 20.0 & 40.0 & 60.0 & 80.0 \\
\hline Total & 1000.0 & 1000.0 & 1000.0 & 1000.0 & 1000.0 \\
\hline \multicolumn{6}{|l|}{ Chemical composition of diets } \\
\hline Dry matter $\left(\mathrm{g} \mathrm{kg}^{-1}\right)$ & 494.5 & 497.5 & 500.6 & 503.6 & 506.7 \\
\hline Organic matter $\left(\mathrm{g} \mathrm{kg}^{-1} \mathrm{DM}\right)$ & 933.1 & 933.3 & 933.5 & 933.8 & 934.0 \\
\hline Crude protein $\left(\mathrm{g} \mathrm{kg}^{-1} \mathrm{DM}\right)$ & 128.2 & 128.3 & 128.4 & 128.5 & 128.5 \\
\hline Ether extract $\left(\mathrm{g} \mathrm{kg}^{-1} \mathrm{DM}\right)$ & 26.0 & 44.8 & 63.6 & 82.4 & 101.2 \\
\hline $\mathrm{NDF}^{(1)}\left(\mathrm{g} \mathrm{kg}^{-1} \mathrm{DM}\right)$ & 523.8 & 517.6 & 511.5 & 505.3 & 499.1 \\
\hline $\mathrm{ADF}^{(2)}\left(\mathrm{g} \mathrm{kg}^{-1} \mathrm{DM}\right)$ & 265.7 & 260.8 & 255.8 & 250.8 & 245.8 \\
\hline $\operatorname{Lignin}\left(\mathrm{g} \mathrm{kg}^{-1} \mathrm{DM}\right)$ & 39.4 & 39.2 & 39.0 & 38.8 & 38.6 \\
\hline Cellulose $\left(\mathrm{g} \mathrm{kg}^{-1} \mathrm{DM}\right)$ & 202.3 & 201.5 & 200.7 & 200.0 & 199.2 \\
\hline $\mathrm{TCH}^{3}\left(\mathrm{~g} \mathrm{~kg}^{-1} \mathrm{DM}\right)$ & 778.8 & 760.2 & 741.5 & 722.8 & 704.1 \\
\hline $\mathrm{NFC}^{4}\left(\mathrm{~g} \mathrm{~kg}^{-1} \mathrm{DM}\right)$ & 264.4 & 251.7 & 239.1 & 226.4 & 213.7 \\
\hline
\end{tabular}

Source: Authors elaboration; ${ }^{1}$ Neutral detergent fiber; ${ }^{2}$ Acid detergent fiber; ${ }^{3}$ Total carbohydrates; ${ }^{4}$ Non-fibrous carbohydrates.

Five castrated lambs of undefined breed with initial body weights of $36.8 \pm 3.3 \mathrm{~kg}$ were used. The animals were kept in cages with individual feeders and waterers for the metabolism trial. For total feces collection, collector bags were used. The animals were weighed at the beginning and the end of each evaluation period for diet adjustments. Each trial period lasted 15 days; the first 10 days were for diet adaptation. Experimental animals were submitted to the pre-experimental period (approximately 15 days) for adaptation to the metabolic cage, routine handling and feeding. Diets were given as a whole mixture twice a day at 7 a.m. and 4 p.m. to minimize feed loss by animals. The food that was offered and any uneaten leftovers was weighed daily, and data collected regarding the feeding portions for each animal during each trial period were later analyzed. Offered food and leftovers as well as feces and urine were sampled from the 11th to 14 th days of each trial period to determine intake, nutrient digestibility and nitrogen balance. Solid samples (supplied diet, leftovers and feces) were placed in plastic bags, identified, and frozen at a temperature of $-18^{\circ} \mathrm{C}$ immediately after collection. At the end of the experimental period, the samples were thawed and dried in forced air ovens at a temperature of $55^{\circ} \mathrm{C}$ for 72 hours. Subsequently, the samples were milled in a Willey-type mill with a sieve of $1 \mathrm{~mm}$.

The chemical composition was identified using the methodology described by Mizubuti et al. 
(2009) for determining the content of dry matter (DM), crude protein (CP), ether extract (EE), ash, neutral detergent fiber (NDF), acid detergent fiber (ADF) and lignin.

On the 11th day of each experimental period, intake behavior was evaluated by measuring the time intervals spent on feeding, rumination and resting; visual observations were performed every 5 minutes over 24 hours (JOHNSON; COMBS, 1991) and artificial lighting was used during nighttime observations. On the same day, every animal was observed in three different periods of the day (10 $\mathrm{h}-12 \mathrm{~h}, 14 \mathrm{~h}-16 \mathrm{~h}$ and $18 \mathrm{~h}-20 \mathrm{~h}$ ). The number of chews per ruminal bolus (number bolus-1) was assessed, and the time spent on rumination was recorded (seconds bolus ${ }^{-1}$ ). This procedure was performed using stopwatches handled by four observers strategically placed so as not to disturb the animals.

The number of boluses ruminated each day was obtained as follows: total rumination time (minutes) divided by the average time spent on the rumination of a bolus. The content of DM and NDF in each ruminated bolus ( $\mathrm{g}$ ) was obtained by dividing the amount of DM and NDF consumed $\left(\mathrm{g} \mathrm{day}^{-1}\right)$ in 24 hours by the number of boluses ruminated each day.

Feeding and rumination efficiency was obtained as follows:

$$
\begin{aligned}
\text { FEDM } & =\mathrm{DMI} / \mathrm{FT} ; \\
\text { FENDF } & =\mathrm{NDFI} / \mathrm{FT} ;
\end{aligned}
$$

where FEDM is DM consumed $\mathrm{g} \mathrm{h}^{-1}$; FENDF (consumed NDF $\mathrm{g} \mathrm{h}^{-1}$ ) = feeding efficiency; DMI $(\mathrm{g})$ $=$ daily intake of dry matter; $\operatorname{NDFI}(\mathrm{g})=$ daily intake of NDF; and FT = time daily spent on feeding.

\section{RUEDM DMI/ RUT;}

\section{RUENDF=NDFI/ RUT}

where RUEDM is ruminated DM g h-1; RUENDF (ruminated NDF $\mathrm{g} \mathrm{h}^{-1}$ ) = rumination efficiency; and RUT $\left(\mathrm{h} \mathrm{day}^{-1}\right)=$ rumination time. The ingestive behavior and its variables were conducted as described by (BÜRGER et al., 2000).
The experimental design was a Latin square (5 $x$ 5) with five levels of inclusion of residual frying oil, five periods of sampling and five animals (experimental units), and in each period, one animal received a different diet. However, for data relating to time spent feeding, ruminating and resting, the experimental design was a Latin square $(5 \times 5)$ in a parcel-subdivided scheme with the inclusion levels of residual oil in the parcel and the shifts (7 $\mathrm{h}-12: 59 \mathrm{~h}$ (morning); $13 \mathrm{~h}-18: 59 \mathrm{~h}$ (afternoon); $19 \mathrm{~h}-00: 59 \mathrm{~h}$ (night) and $1 \mathrm{~h}-6: 59 \mathrm{~h}($ dawn)) in the subparcel. Data were submitted to a normality test for the distribution of errors (Shapiro-Wilk test) and a homogeneity variance test (Levene's test) subsequent to analysis of variance $(\alpha=0.05)$. Mean values were studied by regression analysis (parcel) using a " $\mathrm{t}$ " test $(\alpha=0.05)$ and a Tukey test (subparcel), applying the statistical package $\mathrm{R}$ (2013).

\section{Results and Discussion}

With the reduction in intake of dry matter and neutral detergent fiber (Table 2) to the extent that there has been increased participation of the residual frying oil (RFO) in the diets, decreased time spent on feeding and rumination and increased time resting were expected.

According to Van Soest (1994), the NDF content in a diet influences the time spent feeding and ruminating due to the resistance of the fiber fraction to reduce particle size. However, this was not observed (Table 2). A similar result was verified by Azevedo et al. (2013) while evaluating diets with macaúba cake for cows, the authors attributed the result to particle size of the co-product, which reduced the effectiveness of NDF, which explains the similarity in the behavioral variables analyzed. However in the present study, the fact that diets did not affect the ingestive activity may be due to the animals spending more time in the trough with the selection of food. 
Table 2. Total time spent feeding, ruminating and resting, dry matter and neutral detergent fiber intake, total chewing time (minutes), number of ruminated boluses (number day ${ }^{-1}$ ), chewing (number day ${ }^{-1}$ ), chews for bolus and mean time of rumination by bolus (seconds) in sheep fed diets containing different levels of residual frying oil.

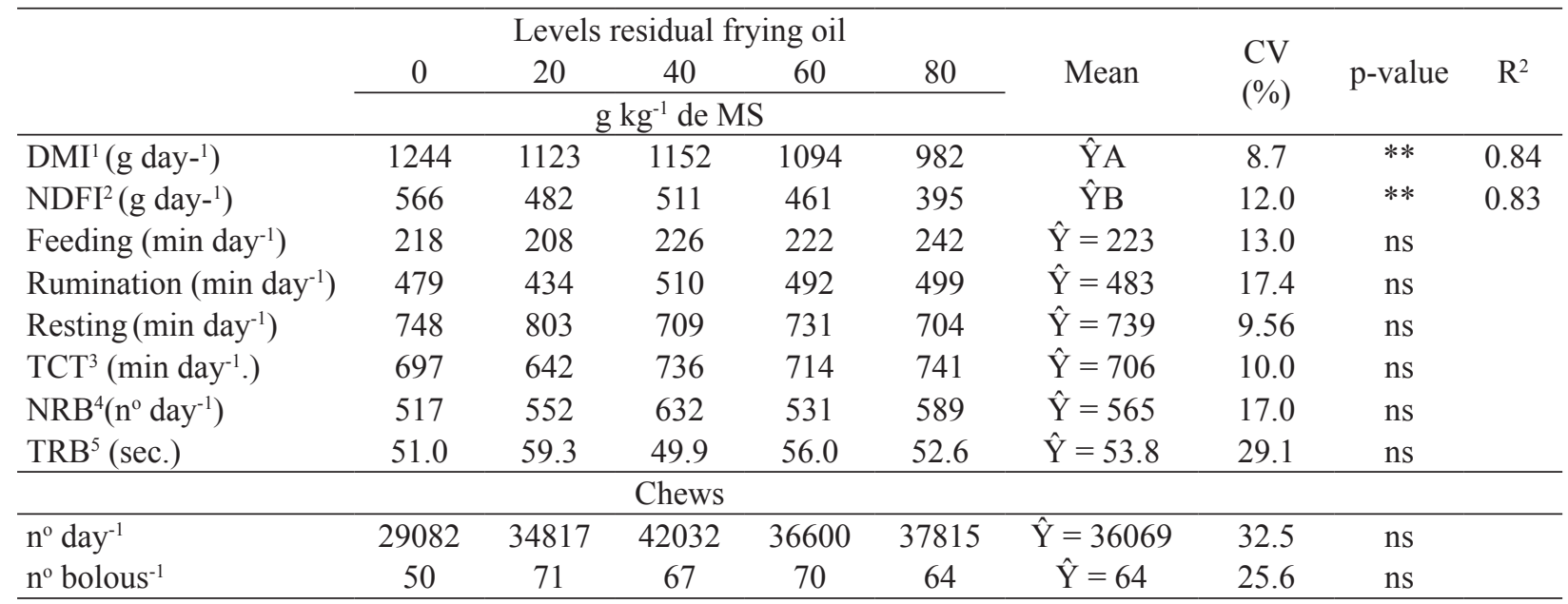

${ }^{1} \mathrm{DMI}=\mathrm{dry}$ matter intake, ${ }^{2} \mathrm{NDFI}=$ neutral detergent fiber intake, ${ }^{3} \mathrm{TCT}=$ Total chewing, ${ }^{4}$ Number of ruminated bolus, $5 \mathrm{TRB}=\mathrm{Time}$ rumination bolus, $\mathrm{CV}=$ coefficient variation, $* *$ Significant at $5 \%$ by $\mathrm{t}$-test, $\mathrm{ns}-$ not significant, $\hat{\mathrm{Y}} \mathrm{A}=1230-28 \mathrm{x}, \hat{\mathrm{Y}} \mathrm{B}=555-0,18 \mathrm{x}$.

The addition of the RFO most likely increased the time required to reduce the particle size of the rumen, consequently increasing the ruminating time; however, such a diet would normally decrease rumination due to the reduction in NDF (Table 2). This is related to the negative impact lipids have on ruminal fermentation, inhibiting the development of cellulolytic microorganisms (MARTINELE et al., 2008). The mean total time spent on feeding, rumination and resting are in accordance with results reported in the literature. Cardoso et al. (2006) observed 205, 483 and 744 minutes spent on feeding, rumination and resting, respectively, for lambs fed diets containing different levels of neutral detergent fiber. Similarly, Gonçalves et al. (2012), who studied the feeding behavior of sheep fed with the by-product of corn ensiled with elephant grass, observed average times of 255, 422 and 710 minutes for feeding, rumination and resting, respectively.

There was no interaction between the levels of RFO and periods of the day for the activities of feeding, rumination and resting. There was a higher feeding time during periods when diets were supplied ( $8 \mathrm{~h}$ to $12 \mathrm{~h}$ and $16 \mathrm{~h}$ to $20 \mathrm{~h}$, Figure 1 ). This type of behavior at feeding time is characteristic of ruminant feedlots, where animals are presented with two main meals (for 1-3 hours) plus a variable number of small meals in between. Fischer et al. (2000) and Castro et al. (2009) also reported this fact.

There was an interaction between rumination time (Figure 1) and period of the day. During the night, rumination was the most common activity with two peaks: the first peak was between $00 \mathrm{~h}$ and $4 \mathrm{~h}$, and the second peak was more intense after 4 h. The period of lowest incidence of rumination was observed during the day, mainly during feeding time. In general, animals ruminated more at night and early morning periods when the ambient temperature is lower. According to Castro et al. (2009), feeding directly influences the distribution of rumination activity because there is greater rumination soon after feeding periods when the animal is still. This fact was observed in this study because most times after ingestion, there was an increase of rumination activity to process the food previously ingested. The same abovementioned researchers, studying the behavioral responses of dairy heifers, also found similar behavior regarding rumination activity in various periods of the day. Ribeiro et al. (2007), 
who studied the feeding behavior of Canindé and Moxotó goats, also observed distinct peaks in feeding, noting that rumination was more active in the evening and during the early morning. According to Leek (2006), the occurrence of rumination has a circadian rhythm and is more commonly associated with a state of drowsiness, occurring more intensely during the night.

Figure 1. Time spent feeding (a) and ruminating (b) at various periods of the day.
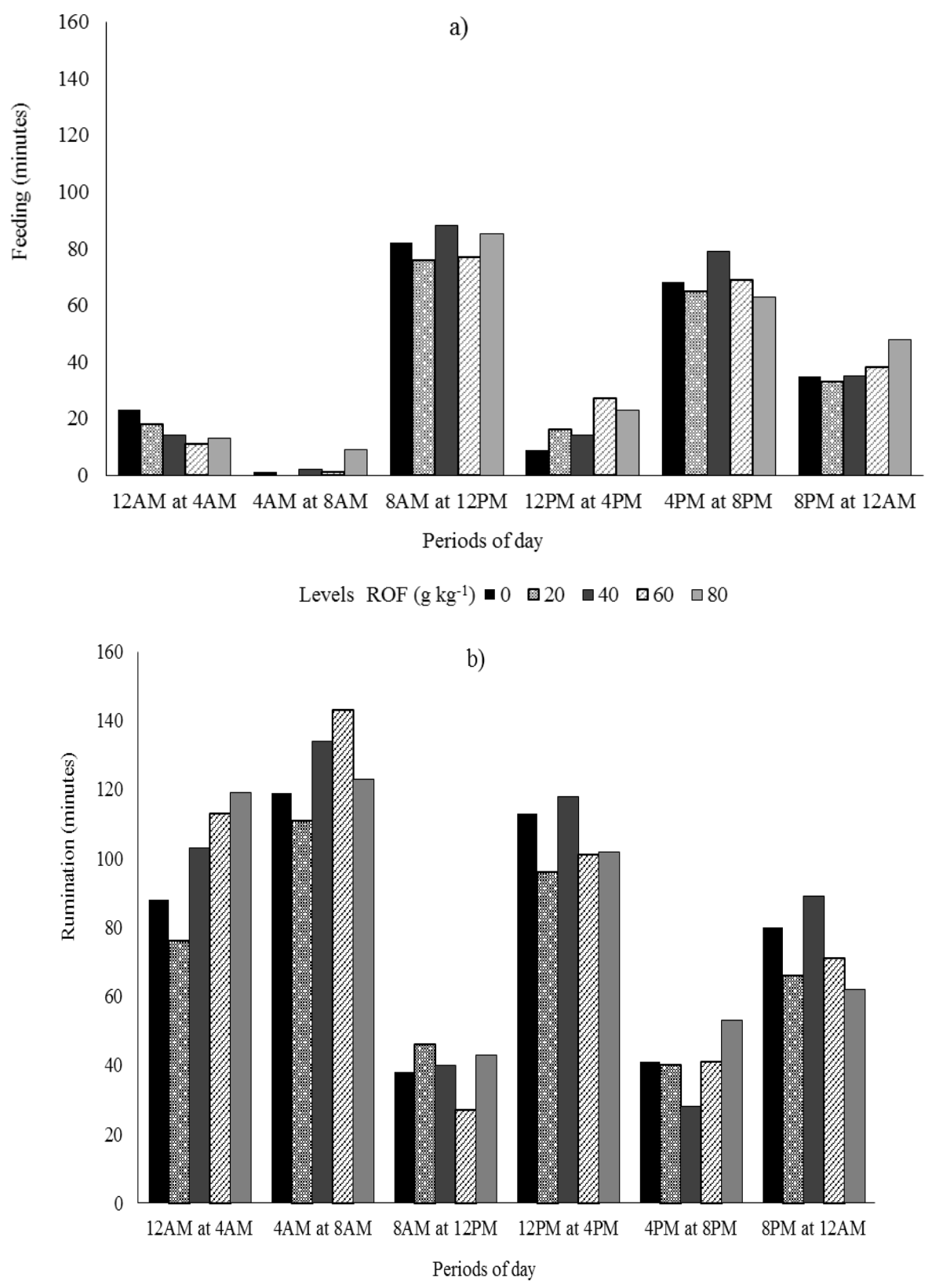

Levels of ROF $\left(\mathrm{g} \mathrm{kg}^{-1}\right) \quad \square 0 \quad \square \quad \square \quad \square 0 \quad \square 60 \quad \square 80$ 
There were no differences between diets containing levels of RFO for the following variables: number of ruminal boluses, number of chews by day, chews per bolus and rumination time by bolus (Table 2). According to Furlan et al. (2006), approximately 360-790 feed boluses are normally ruminated per day with 40-70 mandibular movements in periods of 45-60 seconds, and in this study, data for these three variables are presented within the range proposed by researchers. Alves et al. (2010), who studied the feeding behavior of sheep fed bran mesquite pods, obtained averages very similar to the behavior found here for the number of boluses ruminated (598 bolus day ${ }^{-1}$ ), time spent chewing per bolus (47 seconds bolus ${ }^{-1}$ ), number of chews per bolus (61 chew bolus ${ }^{-1}$ ) and number of chews $\left(36209\right.$ chews day $\left.{ }^{-1}\right)$. Most likely, these factors were not affected by RFO levels because the particle size of the feed was unmodified and because sorghum silage greatly influenced the diets; these two factors were not altered by the addition of RFO.

The feeding efficiency of dry matter and neutral detergent fiber was not influenced by RFO levels (Table 3). This fact contradicts the expectations because the intake of these components was reduced by the addition of RFO (Table 2). Conversely, Freitas et al. (2010) and Agy et al. (2012) found that feeding efficiency is influenced by the intake of component nutrition (DM and NDF). However, the effect of RFO levels on feeding efficiency has not been verified by regression analysis. Higher levels $\left(80 \mathrm{~g} \mathrm{~kg}^{-1} \mathrm{DM}\right)$ of RFO were associated with a lower intake efficiency, demonstrating that the animals receiving a diet with RFO content needed to spend more time selecting food in the trough.

There was a significant linear decreasing effect of rumination efficiency of dry matter when expressed in $\mathrm{g} \mathrm{h}^{-1}$ and $\mathrm{g}$ bolus $\mathrm{s}^{-1}$ and a linear increasing effect when expressed in minutes $\mathrm{kg}^{-1} \mathrm{DM}$. Rumination efficiency of neutral detergent fiber exhibited a linear increasing response when expressed in minutes kg-1 NDF and a linear decreasing effect when expressed in g cicle-1 (Table 3). The decrease in the intake of these compounds with the inclusion of the ORF is one of the causes of the reduction in rumination efficiency of DM and NDF. The results reported here are similar to those described by Jesus et al. (2010), who evaluated the feeding behavior and physiological responses of goats fed diets with different levels of licuri oil. Similarly, Carvalho et al. (2004) evaluated cocoa meal or palm kernel cake in diets for dairy goats and found no differences in intake efficiency; however, they noted less rumination efficiency for diets with higher levels of cocoa meal due to lower intakes of DM and NDF. 
Table 3. Feeding and rumination efficiency of dry matter (DM) and neutral detergent fiber (NDF) in sheep fed diets containing different levels of residual frying oil.

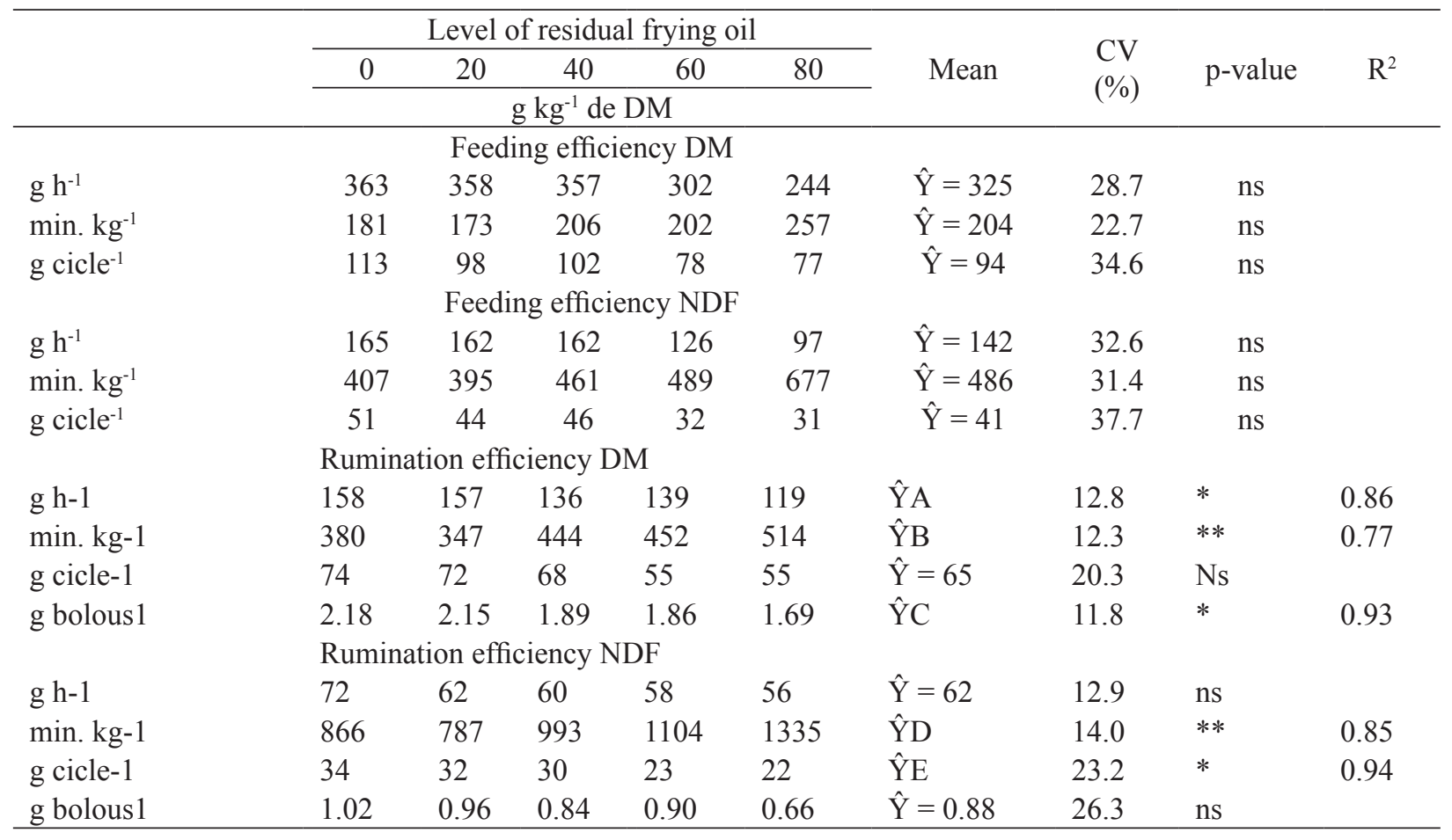

$\mathrm{CV}=$ coefficient variation, $\mathrm{ns}-$ not significant, $*$ Significant at 1 and $5 \%$ by t-test, $\hat{\mathrm{Y}} \mathrm{A}=161-4.82 \mathrm{x} ; \hat{\mathrm{Y}} \mathrm{B}=358.17+17.74 \mathrm{x} ; \hat{\mathrm{Y} C}=$ $2,21-0.06 x ; \hat{Y} \mathrm{D}=766.38+62.73 x ; \hat{\mathrm{Y}} \mathrm{E}=34.87-1.65 \mathrm{x}$.

\section{Conclusions}

The inclusion of residual frying oil in the diets influenced neither the activities of feeding, rumination and resting nor the parameters of chewing in lambs. However, rumination efficiency was reduced with the addition of residual frying oil. There is a predominance of intake activity after feeding and rumination activities overnight.

\section{Acknowledgements}

The authors thank the Conselho Nacional de Desenvolvimento Científico e Tecnológico (CNPq), the granting of financial resources for project implementation.

\section{References}

AGY, M. S. F. A.; OLIVEIRA, R. L.; CARVALHO, G. G. P.; LEÃO, A.G.; RIBEIRO, O. L.; BADALGO, A. R.; RIBEIRO, R. D. X.; RIBEIRO, M. D. Comportamento ingestivo e respostas fisiológicas de cabritos alimentados com dietas contendo torta de girassol oriunda da produção de biodiesel. Arquivo Brasileiro de Medicina Veterinária e Zootecnia, Belo Horizonte, v. 64, n. 5, p. 1292-1301, 2012.

ALVES, E. M.; PEDREIRA, M. S.; OLIVEIRA, C. A. S.; AGUIAR, L. V.; PEREIRA, M. L. A.; ALMEIDA, P. J. P. Comportamento ingestivo de ovinos alimentados com farelo da vagem de algaroba associado a níveis de ureia. Acta Scientiarum. Animal Sciences, Maringá, v. 32, n. 4, p. 439-445, 2010.

AZEVEDO, R. A.; SANTOS, A. C. R.; RIBEIRO JÚNIOR, C. S.; BICALHO, F. L.; BAHIENSE, R. N.; ARAÚJO, L.; GERASEEV, L. C. Comportamento ingestivo de vacas alimentadas com torta de macaúba. Ciência Rural, Santa Maria, v. 43, n. 8, p. 1485-1488, 2013. 
BÜRGER, P. J.; PEREIRA, J. C.; QUEIROZ, A. C. D.; SILVA, J. D.; VALADARES FILHO, S. D. C.; CECON, P. R.; CASALI, A. D. P. Comportamento ingestivo em bezerros holandeses alimentados com dietas contendo diferentes níveis de concentrado. Revista Brasileira de Zootecnia, Viçosa, v. 29, n. 1, p. 236-242, 2000.

CARDOSO, A. R.; CARVALHO, S.; GALVANI, D. B.; PIRES, C. C.; GASPERIN, B. G.. Comportamento ingestivo de cordeiros alimentados com dietas contendo diferentes níveis de fibra em detergente neutro. Ciência Rural, Santa Maria, v. 36, n. 2, p. 604-609, 2006.

CARVALHO, G. G. P.; PIRES, A. J. V.; SILVA, F. F.; VELOSO, C. M.; SILVA, R. R. S.; SILVA, H. G. O.; BONOMO, P.; MENDONÇA, S. S. Comportamento ingestivo de cabras leiteiras alimentadas com farelo de cacau ou torta de dendê. Pesquisa Agropecuária Brasileira, Brasília, v. 39, n. 9, p. 919-925, 2004.

CARVALHO, G. D.; PIRES, A. J. V.; SILVA, R. R.; VELOSO, C. M.; SILVA, H. D. O. Comportamento ingestivo de ovinos alimentados com dietas compostas de silagem de capim-elefante amonizada ou não e subprodutos agroindustriais. Revista Brasileira de Zootecnia, Viçosa, v. 35, n. 4, p.1805-1912, 2006.

CASTRO, K. J. D.; MIRANDA NEIVA, J. N.; SILVA FALCÃO, A. J. D.; ROCHA CHAVES MIOTTO, F.; CARNEIRO, R. O. Respostas comportamentais de novilhas leiteiras alimentadas com dietas à base de subprodutos agroindustriais. Revista Ciência Agronômica, Fortaleza, v. 40, n. 2, p. 306-314, 2009.

FISCHER, V.; DUTILLEUL, P.; DESWYSEN, A. G.; DĖSPRES, L.; LOBATO, J. F. P. Aplicação de probabilidades de transição de estados dependentes do tempo na análise quantitativa do comportamento ingestivo de ovinos. Parte I. Revista Brasileira de Zootecnia, Viçosa, v. 29, n. 6, p.1811-1820, 2000.

FREITAS, L. S.; SILVA, J. H. S.; SEGABINAZZI, L. R.; SILVA, V. S.; ALVES FILHO, D. C.; BRONDANI, I. L. Substituição da silagem de milho por silagem de girassol na dieta de novilhos em confinamento: comportamento ingestivo. Revista Brasileira de Zootecnia, Viçosa, v. 39, n. 1, p. 225-232, 2010.

FURLAN, R. L.; MACARI, M.; FARIA FILHO, D. E. Anatomia e fisiologia do trato gastrintestinal. In: BERCHIELLI, T. T.; PIRES, A. V.; OLIVEIRA, S. G. (Ed.). Nutrição de ruminantes. FUNEP, Jaboticabal. 2006. p. 403-421.
GONÇALVES, M. F.; SANTOS, S. F.; SOUZA, J. T. L.; ANDRADE, M. E. B.; OLIVEIRA, M.V.; PANIAGO, A. B.; SCHULTZ, E. B.; MACEDO JUNIOR G. L.; FERREIRA I. C. Comportamento ingestivo de ovelhas alimentadas com coproduto do milho ensilado com capim-elefante. Veterinária Notícias, Uberlândia, v. 18, n. 2, p. 124-128, 2012.

JESUS, I. B.; BAGALDO, A. R.; BARBOSA, L. P.; OLIVEIRA, R. L.; GARCEZ NETO, A. F.; SILVA, T. M.; MACOME, F. M.; MARTINS, L. E. P. Comportamento ingestivo e respostas fisiológicas de cabritos 3/4 Boer submetidos a dietas com níveis de óleo de licuri. Revista Brasileira de Saúde e Produção Animal, Salvador, v. 11, n. 4, p. 1176-1186, 2010.

JOHNSON, T. R.; COMBS, D. K. Effects of prepartum diet, inert rumen bulk, and dietary polyethylene glycol on dry matter intake of lactating dairy cows. Journal Dairy Science, Champaign, v. 74, n. 3, p. 933-944, 1991.

LEEK, B. F. Digestão no estômago do ruminante. In: REECE, W. O. (Ed.). dukes fisiologia dos animais domésticos. Guanabara Koogan, Rio de Janeiro. 2006, p. 404-437.

MACEDO, C. A. B.; MIZUBUTI, I. Y.; MOREIRA, F. B.; PEREIRA, E. S.; RIBEIRO, E. L. A.; ROCHA, M. A.; RAMOS, B. M. O.; MORI, R. M.; PINTO.; ALVES, T. C.; CASIMIRO, T. R. Comportamento ingestivo de ovinos recebendo dietas com diferentes níveis de bagaço de laranja em substituição à silagem de sorgo na ração. Revista Brasileira de Zootecnia, Viçosa, v. 36, n. 6, p. 1910-1916, 2007.

MARTINELE, I.; EIFERT, E. D. C.; LANA, R. D. P.; ARCURI, P. B.; D'AGOSTO, M. Effect of monensin and soybean oil on rumen ciliate protozoa and correlation between protozoa with ruminal fermentation and digestive parameters. Revista Brasileira de Zootecnia, Viçosa, v. 37, n. 6, p. 1129-1136, 2008.

MIZUBUTI, I. Y.; PINTO, A. P.; PEREIRA, E. S.; RAMOS, B. M. O. Métodos laboratoriais de avaliação de alimentos para animais. EDUEL- Editora da Universidade Estadual de Londrina, Londrina, 2009.

NATIONAL RESEARCH COUNCIL - NRC. Nutrient requirements of small ruminants: sheep, goats, cervids and new world camelids, Washington, D.C.: National Academy Press, 2007. 384 p.

RIBEIRO, V. L.; BATISTA, Â. M. V.; CARVALHO, F. F. R.; MATTOS, C. W.; ALVES, K. S. Comportamento ingestivo de caprinos Moxotó e Canindé submetidos à alimentação à vontade e restrita. Acta Scientiarum. Animal Sciences, Maringá, v. 28, n. 3, p. 331-337, 2007 
RODRIGUES FILHO, M. Características de carcaça e qualidade da carne de tourinhos red norte suplementados com óleos de fritura e de soja. 2011. Tese (Doutorado em Zootecnia) - Universidade Federal de Lavras, Lavras, 2011.
SILVA, M. M. C.; RODRIGUES, M. T.; BRANCO, R. H.; RODRIGUES, C. A. F.; SARMEMTO, J. L. R.; QUEIROZ, A. C.; SILVA, S. P. Suplementação de lipídios em dietas para cabras em lactação: consumo e eficiência de utilização de nutrientes. Revista Brasileira de Zootecnia, Viçosa, v. 36, n. 1, p. 257-267, 2007.

VAN SOEST, P. J. Nutrition ecology of the ruminant. 2. ed. Ithaca: Comstock Publishing Associates, 1994. 